\title{
SALE AND VALUATION OF A PART OF A BUSINESS UNIT IN THE IDENTIFICATION OF OPERATING ASSETS
}

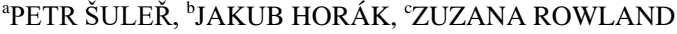

anstitute of Technology and Business in České Budějovice, School of Expertness and Valuation, Okružní 517/10 37001 České Budějovice, Czech Republic

binstitute of Technology and Business in České Budějovice, School of Expertness and Valuation, Okružní 517/10 37001 České Budějovice, Czech Republic

'Institute of Technology and Business in České Budějovice, School of Expertness and Valuation, Okružní 517/10 37001 České Budějovice, Czech Republic email: ${ }^{a}$ petr.suler@cez.cz, ${ }^{b}$ horak@mail.vstecb.cz, rrowland@mail.vstecb.cz

Abstract: The aim of this paper is to value a portion of a company which is able to turn profit even after separation from the whole. The assets of the company are identified, which are operationally necessary for the further functioning of the valuated part as a separate accounting unit. The earnings and asset valuation methods are used to valuate the part of the company. The results of the market value of the company achieved using both methods are compared in the end and the reasons for the differences in the achieved results are stated. The difference in the results achieved by different valuation methods is due to modifications of the input data, which enter the calculation of the value of the company using the individual valuation methods used. The reason for these modifications is also explained.

Keywords: part of a business, operating assets, non-operating assets, assets of a functional accounting unit.

\section{Introduction}

Expertise and valuation practice is constantly dealing with the valuation of companies. Requirements for the valuation of a company are demanded primarily by the courts, which in some cases need to know the professional, impartial and factual and data-based opinion on the value of a company that is the subject of a litigation. The second group of applicants for the valuation of a company consists mainly of its owners, who need to know this information for various personal or business reasons.

In both cases, it is necessary for the appraiser to maintain an overview of the whole problem when valuing the company and to approach its solution as a third impartial rationally thinking person. Only with this approach can the best, impartial and unbiased result of a valuation be ensured.

A company can be valuated as a whole, which most often occurs when it is sold. Furthermore, only certain parts of the company can be valuated, which however do not form a functional unit together. These can be individual items or entire sets of tangible assets, intangible assets, movable property, etc. Last but not least, only a portion of the company can be valuated. This occurs especially if the company consists of individual independently functional sub-parts (departments, divisions, etc.) and its owner or owners decide to sell this part of the company, regardless of their personal or business reasons.

The aim of this contribution is to valuate a separately functional part of the company, which will be able to generate a profit as a separate unit even after it has been separated (sold) from the rest of the unit. The process of valuating a self-sufficient part of a company will be demonstrated on the model company XYZ, which operates in the field of hardware, software, mobile services and internet. Specifically, it will be a valuation of the portion of the XYZ model company that provides services in the area of internet.

\section{Literature research}

The process of valuating the company involves the gathering of individual steps, where for each of them the maximum precision of the valuator matters. The use of these specific individual steps in the desired order is required when using a particular valuation method. Even with the right choice and use of a particular valuation method, the valuation result may be incorrect. Audretsch and Link (2012) addressed the shortcomings of valuation methods used in valuating companies. Therefore, the use of traditional valuation methods is not recommended, especially for small businesses. Fernández (2005) has already made a list of possible errors that appraisers may make. It highlights possible errors in working with input data, errors in determining the weighted average cost of capital (WACC), errors in valuating companies that generate profit only seasonally and errors in determining the residual price of the company. Mizik and Jacobson (2009) dealt with the valuation of corporate brands using a multiplier approach. According to their findings, the assets of the valuated company do not fully participate in the result of the valuation process due to the fact that the value of the brand of the company is not taken into account among these valuated assets.

Cassia and Vismara (2009) examined the market price of a young (expanding) company if, based on an analysis of its previous financial statements, it can be determined that within 12 months the company will be able to fully cover its own operating costs, including the cost of equity. Therefore, they determined the ideal rate of growth in the value of the company, so that this situation would eventually occur safely. Therefore, they used the Logit and Cox regression models and found that the size of the deviation from the predictive value of the company has an effect on the deviation from the set time of the 12month horizon.

Classic valuation models are always based on the accounting data of the valuated company. According to Sedláček (2010), specific assets do not have to penetrate into the company's financial statements and may therefore be omitted by the appraiser during the valuation process. These are usually the intangible assets of the company. This lack of financial reporting can therefore have a very negative impact on the resulting determined value of the company. Ionita and Stoica (2009) point out the same thing. They note that the goodwill of a company is usually not visible from the customer's point of view, and therefore customers do not take this value-creating asset into account when evaluating individual companies in the decisionmaking process on the purchase of goods in a particular company. However, this aspect should be addressed by the appraiser.

Miciula et al. (2020) note that the valuation methods used by the valuator should be in line with the MDI-R concept, which takes into account the company's assets, its income and the company's intellectual capital, including its intangible assets. Stehel et al. (2019a) dealt with the valuation of a company's intangible assets. To value it, they used the difference between the company's final values determined using the asset and earnings methods. Abhayawansa et al. (2015) again examined what intangible assets are included in the valuation of a company and what is the justification for its inclusion in the valuation process by the appraiser. Stehel et al. (2019b) also focused on the valuation of a company's small tangible assets as part of the valuation of individual assets of the company.

The results of the valuation itself, i.e. the results of the work of the valuator, as an impartial third party, are a valuable source of information for potential investors. Kouki (2015) focused on the impact of the voluntary adoption of IFRS in the period from 2000 to 2004, when the use of IFRS was not yet mandatory, on the book value of the company from the perspective of investors. They compared GAAP as historical accounting data and accounting data maintained in accordance with the IFRS model. Determining the value of a company for the needs of investors on the basis of accounting data kept in accordance with IFRS provides more relevant data for determining the fair value of a company than GAAP. 
Collewaert and Minigart (2016) examined the view of angel investors on the company they help to set up with their capital, in terms of the future value, that this angel investor will have in the future from the ownership share in the founding company, or a share in the profit. Angel investors prefer to invest in companies that are founded by intellectually gifted people. Regarding these people, investors value their intellectual capital.

Stancu et al. (2017) dealt with individual methods of company valuation and looked for differences between them. These methods were Discounted Cash Flow (DCF), Market Value Added (MVA) and Residual Income (RI). Based on the performed analysis of the comparison of individual valuation methods, no significant differences were found in the results achieved by individual methods.

Rowland et al. (2019) determined the market value of a company using a modified method of determining capitalized net income. When all the conditions for the input data are met when valuating the company using this method, they state the universal applicability of this method to determine the market value of a company from any industry.

In the case of valuation of companies operating in the information and communication (ICT) sector, the composition of their assets is very specific. This is mainly due to the relatively high share of intangible assets. Langenstein and Uzik (2015) dealt with the specifics of valuating companies operating in Germany in the ICT sector. The value of these companies ranged from one to 28 million euros. The values of the companies, based on the capital of the individual companies, ranged from two to eight million euros. However, it is necessary to use such valuation methods that take into account the intangible assets of companies operating in the ICT sector, otherwise the results are very skewed.

However, the very value of the ICT sector lies in the fact that thanks to this sector, other sectors are able to innovate in the field of ICT. Thanks to these innovations, companies operating in other sectors can also increase their value. Hidalgo and Herrera (2020) therefore analyzed how the ICT sector can contribute to the co-creation of processes carried out in other sectors. According to Barba-Sanchez et al. (2018) the performance of a company depends on the level of use and implementation of new ICT. However, companies that have already implemented these technologies in their production processes very often have to replace these technologies with new ones, because the ICT sector is a very dynamically developing sector and very often comes to the market with new technologies. Belvedere and Grano (2017) state that a company can increase its profitability by providing ICT consulting services, at least to address issues related to the services or products it provides. Jarmooka et al. (2020) dealt with the connection of ICT, knowledge management processes (KMP) and innovation. Based on the achieved results, they also state that the implementation of ICT and KMP has a positive effect on the innovative performance of a company. They therefore recommend the involvement of ICT and KMP in the company's innovation program.

The ICT sector is also specific in that it will drive business in other sectors to the next level by innovating it. It is also able to increase the competitiveness of a company by providing new and innovative technologies and participating in their implementation in other industries. However, this development also entails higher requirements for the security of IT systems (Lee and Chang, 2014).

Thanks to ICT, the Industry 4.0 program could be realized, which implements the latest technologies, especially in manufacturing companies. However, this program, which works on the basis of remote management of manufacturing processes via the internet interface, requires fast $5 \mathrm{G}$ data networks so that the system can quickly return information about the current state of all monitored variables. Therefore, it is essential for a company that has decided to modernize its production process through the Industry 4.0 program to solve its internet connection and overall connectivity throughout the company very well. In this respect, ICT companies, which deal with network infrastructure solutions and the provision of internet connections (Kim, 2020), will have high demand. From this point of view, the area of the ICT sector dealing with providing internet connection and network infrastructure solutions can be considered highly lucrative in the future, and companies that already have a good client base can increase their profits. According to Tuffnell et al. (2019), revenues from artificial intelligence, the implementation of which into production processes is included in the Industry 4.0 program, will continue to rise. In 2025, artificial intelligence is expected to account for $\$ 31,239.41$ mil. in global market revenue.

A company which is operating in the ICT sector also includes tangible assets, which have the character of real estate. Before construction this construction project is necessary to develop a schedule of total costs for the construction. Beran and Hromada (2008) for this purpose, they have already published a model, which can be used to predict the expected costs and the schedule required to realize a construction project.

\section{Materials and methods}

The XYZ model company is run by two partners, with one of the partners participating in the operation of the valuated part of the model company by only $10 \%$ (employee management). Furthermore, the model company XYZ employs two employees who take care of the operation of the valuated part of the subject model company XYZ. The second of the partners does not participate in the operation or management of the valuated part of the model company XYZ.

First, the identification of the accounting entries of the valuated part of the model company XYZ will be identified, which will form a separate functional part capable of generating a profit even after this division is separated from the remaining part of the model enterprise XYZ. Subsequently, an earnings valuation of this partial part of the model company XYZ will be performed. Furthermore, the asset valuation of a part of the model company XYZ will be performed. The valuation of the relevant part of the company will be performed using both valuation methods as of June 30, 2020. The achieved results of both used valuation methods will be subsequently compared.

First, the identification of accounting entries of the valuated part of the model cmpany XYZ, which are necessary from the point of view of maintaining the future functionality of the part of the model company XYZ, will be performed. In the case of the valuated subject part of the model company XYZ, it is a set of assets including a passenger car and tangible fixed assets. In order to use the earnings method to valuate a part of the model company XYZ, it will be necessary to divide the used fixed assets into operating and non-operating. Subsequently, the total investment intensity of the utilized operating tangible fixed assets will be taken into account. First, however, it will be necessary to determine the size of the annual depreciation of fixed assets expressed in CZK. For this we will use formula 1.

$$
\text { Annual depreciation }=\frac{\text { Purchase price }}{\text { Total service life }} \text {. }
$$

Subsequently, it will be possible to determine the degree of investment of tangible fixed assets according to formula 2.

$$
\begin{aligned}
& \text { Investment intensity } \\
& =\frac{(\text { Purchase price }- \text { Annual depreciation })}{\text { Total service life }}
\end{aligned}
$$

The sum of the investment intensity of all entries of tangible fixed assets will determine the total investment intensity of the valuated part of the model company XYZ. 
In order to maintain the subsequent functionality of the part of the model company, it will also be necessary to determine the wage intensity of the employee who, after the separation of the valuated part, will work as one of the partners who takes care of the management of this part of the model company XYZ. The wage intensity of this employee will be determined on the basis of the median gross wage according to the CZ-ISCO classification. It will specifically be group 5 - services and sales workers. Mandatory contributions for the employee's health and social insurance, which are paid by his employer, will then be added to the median gross wage. It will therefore be necessary to increase the median gross wage by $34 \%$ (9 \% health insurance and $25 \%$ social insurance).

Subsequently, on the basis of the provided accounting data and the values determined above, the annual deductible income of the valuated part of the model company XYZ will be calculated. Accounting data from 2017 up until the date of valuation (June 30,2020 ) will be used for this purpose. Depending on the length of time from the valuation date, the weights of the results of annual deductible income will then be determined.

In the next step, the permanently deductible net income will be calculated according to formula 3.

$$
T C V=\frac{\sum_{t=1}^{K} q_{t} \check{\mathrm{C}} V_{t}}{\sum_{t=1}^{K} q_{t}} .
$$

Where: $\quad C V t$ - past adjusted net income,

$q_{t}$ - weights that determine the significance of net income for a particular prior year,

$K$ - number of previous years included in the calculation.

To determine the value of the subject part of the XYZ model company using the earnings valuation method, it will be necessary to determine the discount rate. The discount rate using the earnings valuation method corresponds to the alternative cost of equity $\left(r_{e}\right)$. A comprehensive modular method will be used to determine alternative costs of equity, drawing on data published on the Czech market by the Ministry of Industry and Trade of the Czech Republic (MIT CR) and the Czech National Bank (CNB), which respond to the specifics of the Czech market. This will be data for the second half of 2019, as data from a period closer to the valuation date are not available. Selected according to the CZ NACE code, it will be group "J" (62 - activities in the field of information technology). The modular method for determining alternative cost of equity is set out in Formula 4.

$$
r_{e}=r_{f}+r_{\text {pod }}+r_{\text {finstab }}+r_{L A}
$$

Where: $\quad r_{e}$ - alternative cost of equity,

$$
r_{f} \text { - risk-free yield, }
$$

$r_{\text {pod }}-$ risk premium for business risk,

$r_{\text {finstab }}$ - risk premium for financial stability,

$r_{L A}$ - risk premium for the size of the company.

After performing these calculations, it will be possible to calculate the value of the subject part of the model company XYZ using formula 5.

$$
H P=\frac{T C V}{i_{k}} .
$$

Where: $H P$ - the value of the subject part of the company, $T C V$ - permanently deductible net income, $i_{k}$ - calculated interest rate.

The next step will be the valuation of the subject part of the model company XYZ using the asset valuation method. The sum of all assets of the valuated part of the model company XYZ will be performed. These will be tangible items of both operating and non-operating assets identified using the earnings valuation method. For all items, the annual wear and tear expressed in CZK will first be determined using formula 1. Subsequently, the total depreciation will be determined using formula 6 .

$$
\begin{aligned}
\text { Total depreciation } & =\text { Annual depreciation } \\
& * \text { Asset age }
\end{aligned}
$$

Asset age will always be rounded up in the calculations. Subsequently, the residual price of items of tangible fixed assets of the model company XYZ will be calculated using formula No. 7.

$$
\begin{aligned}
& \text { Residual price of tangible fixed assets } \\
& =\text { Purchase price } \\
& \text { - Total depreciation. }
\end{aligned}
$$

In the case of valuating a passenger car that is part of the operating assets of the valuated part of the XYZ model company, the CabiaCat GT application will be used. Tangible fixed assets will be valuated on the basis of the useful life, annual depreciation and age of the relevant assets.

Furthermore, the financial assets of the model company XYZ will be included in the valuation of the subject part of the model company XYZ using the asset valuation method. These will be residues of financial assets in the treasury and bank accounts on the valuation date. In addition, receivables will be included in the financial assets of the XYZ model company. The liabilities of the valuated $\mathrm{XYZ}$ model company part is the only negative item that enters the asset valuation method and will be deducted from the value of the XYZ model company part determined by the asset method.

Finally, the achieved results of both used valuation methods will be compared.

\section{Results}

First, the accounting entries of fixed assets of the valuated part of the model company XYZ were identified, which will form a separate functional part capable of generating profit even after the separation of this part from the remaining portion of the model company XYZ. These items are listed in Table 1, including total service life and purchase prices.

Table 1: Accounting items of the valuated part of the model company XYZ, including the total service life and purchase prices in CZK

\begin{tabular}{|l|l|c|r|}
\hline ID & \multicolumn{1}{|c|}{ Name } & $\begin{array}{c}\text { Total service life } \\
\text { / age }\end{array}$ & Purchase price \\
\hline 1 & set of devices - internet & $25 / 13.21$ year & $119,918.49$ \\
\hline 2 & set of devices - internet & $25 / 13.08$ year & $115,418.49$ \\
\hline 3 & Server & $25 / 13.04$ year & $91,630.00$ \\
\hline 4 & set of devices - internet & $25 / 12.94$ year & $115,683.83$ \\
\hline 5 & set of devices - internet & $20 / 12.73$ year & $206,750.90$ \\
\hline 6 & Radio contact ORCAVE & $20 / 11.66$ year & $198,000.00$ \\
\hline 7 & $\begin{array}{l}\text { radio contact - antenna } \\
\text { and parabola }\end{array}$ & $20 / 11.05$ year & $93,700.00$ \\
\hline 8 & $\begin{array}{l}\text { Microwave contact A-B } \\
-1\end{array}$ & $20 / 9.62$ year & $21,202.25$ \\
\hline 9 & $\begin{array}{l}\text { Microwave contact A-B - } \\
2\end{array}$ & $20 / 9.62$ year & $21,202.25$ \\
\hline 10 & $\begin{array}{l}\text { Microwave contact A-B - } \\
3\end{array}$ & $20 / 9.62$ year & $21,202.25$ \\
\hline 11 & $\begin{array}{l}\text { Microwave contact A-B - } \\
4\end{array}$ & $20 / 9.62$ year & $21,202.25$ \\
\hline 12 & $\begin{array}{l}\text { Invoice payment no. } \\
110100523 \text { - Server Dell }\end{array}$ & $20 / 8.81$ year & $49,900.00$ \\
\hline 13 & Microwave contact C-D & $20 / 5.7$ year & $91,918.00$ \\
\hline 14 & $\begin{array}{l}\text { network construction }- \\
\text { technical evaluation }\end{array}$ & $20 / 5.66$ year & $130,000.00$ \\
\hline 15 & $\begin{array}{l}\text { Microwave contact - C- } \\
\text { D - technical evaluation }\end{array}$ & $20 / 5.18$ year & $90,460.00$ \\
\hline 16 & Microwave contact & $20 / 4.08$ year & $170,006.00$ \\
\hline 17 & Microwave contact 2 & $20 / 3.66$ year & $179,570.00$ \\
\hline 18 & Microwave contact 2 & $20 / 3.29$ year & $83,702.00$ \\
\hline 19 & Microwave contact 1 & $20 / 3.22$ year & $93,004.00$ \\
\hline
\end{tabular}




\begin{tabular}{|l|l|c|r|}
\hline 20 & Microwave contact 3 & $20 / 2.74$ year & $59,995.00$ \\
\hline 21 & Microwave contact 4 & $20 / 2.62$ year & $79,370.00$ \\
\hline 22 & Dacia Duster & $15 / 2.1$ year & $297,190.00$ \\
\hline Total & $\mathbf{2 , 3 5 1 , 0 2 5 . 7 1}$ \\
\hline
\end{tabular}

Source: Authors.

According to Table 1, it is evident that the identified tangible fixed assets of the valuated part of the model company XYZ have a value of CZK 2,351,025.71 based on the sum of acquisition prices.

Subsequently, these tangible fixed assets were divided into operating and non-operating. In the case of non-operating assets, it is not necessary for financial reserves to be set aside within the company for its renewal, for various reasons, depending on the nature of the specific non-operating assets. In the case of the model company XYZ, the following were included among the non-operating items of fixed assets:

1. Server (item ID 3)

2. Set of devices - internet (item ID 4)

3. Set of devices - internet (item ID 5)

4. Radio contact ORCAVE (item ID 6)

Furthermore, the annual depreciation and investment intensity of each item of operating tangible fixed assets was determined according to formulas 1 and 2 . The results are shown in Table 2 .

Table 2: The amount of annual depreciation and investment intensity of individual items of operating tangible fixed assets of the valuated part of the model company XYZ in CZK

\begin{tabular}{|l|l|r|r|}
\hline ID & \multicolumn{1}{|c|}{ Name } & \multicolumn{1}{c|}{$\begin{array}{c}\text { Annual } \\
\text { depreciation }\end{array}$} & \multicolumn{1}{c|}{$\begin{array}{c}\text { Investment } \\
\text { intensity }\end{array}$} \\
\hline 1 & set of devices - internet & $4,796.74$ & $4,604.87$ \\
\hline 2 & set of devices - internet & $4,616.74$ & $4,432.07$ \\
\hline 7 & $\begin{array}{l}\text { radio contact - antenna and } \\
\text { parabola }\end{array}$ & $4,685.00$ & $4,450.75$ \\
\hline 8 & Microwave contact A-B - 1 & $1,060.11$ & $1,007.11$ \\
\hline 9 & Microwave contact A-B - 2 & $1,060.11$ & $1,007.11$ \\
\hline 10 & Microwave contact A-B - 3 & $1,060.11$ & $1,007.11$ \\
\hline 11 & Microwave contact A-B - 4 & $1,060.11$ & $1,007.11$ \\
\hline 12 & $\begin{array}{l}\text { Invoice payment No. } \\
\text { 110100523 - Server Dell }\end{array}$ & $2,495.00$ & $2,370.25$ \\
\hline 13 & Microwave contact C-D & $4,595.90$ & $4,366.11$ \\
\hline 14 & $\begin{array}{l}\text { network construction } \\
\text { technical evaluation }\end{array}$ & $6,500.00$ & $6,175.00$ \\
\hline 15 & $\begin{array}{l}\text { Microwave contact - C-D - } \\
\text { technical evaluation }\end{array}$ & $4,523.00$ & $4,296.85$ \\
\hline 16 & Microwave contact & $8,500.30$ & $8,075.29$ \\
\hline 17 & Microwave contact 2 & $8,978.50$ & $8,529.58$ \\
\hline 18 & Microwave contact 2 & $4,185.10$ & $3,975.85$ \\
\hline 19 & Microwave contact 1 & $4,650.20$ & $4,417.69$ \\
\hline 20 & Microwave contact 3 & $2,999.75$ & $2,849.76$ \\
\hline 21 & Microwave contact 4 & $3,968.50$ & $3,770.08$ \\
\hline 22 & Dacia Duster & $19,812.67$ & $18,491.82$ \\
\hline Total & & $\mathbf{8 4 , 8 3 4 . 3 8}$ \\
\hline
\end{tabular}

Source: Authors.

According to Table 2, it is evident that the total annual investment intensity of the operating assets of the valuated part of the model enterprise XYZ is CZK 84,834.38.

Furthermore, the wage intensity of the employee who would have to perform managerial activities in the subject part of the model company XYZ, which is the subject of the valuation, which was up to now provided by one of the partners, was determined. Median gross wages for 2017-1. quarters of 2020 were obtained through the Information System on Average Income (www.ispv.cz). Table 3 shows the median gross wages for group 5 - services and sales workers. The values of the median gross wage need to be increased by $34 \%$, which corresponds to $9 \%$ for health insurance and $25 \%$ for social insurance.
Table 3: Median gross wages for group 5 - workers in services and sales in the period 2017-1. quarter of 2020 in CZK

\begin{tabular}{|l|c|c|c|c|}
\hline Year & 2017 & 2018 & 2019 & $\begin{array}{c}1 . q u a r t e r \\
2020\end{array}$ \\
\hline Median gross wage & 18,840 & 21,314 & 22,286 & 23,079 \\
\hline $\begin{array}{l}\text { Median gross wage } \\
\text { increased by } \\
\text { compulsory } \\
\text { contributions (+ 34\%) }\end{array}$ & 25,209 & 28,518 & 29,819 & 30,840 \\
\hline
\end{tabular}

Source: Information system on average income (2020), authors.

Subsequently, on the basis of the provided accounting data and the results of the values determined above, the annual deductible income of the valuated part of the model company XYZ was calculated. Depending on the length of time before the valuation date, the weights of the results of annual deductible income were determined. The results of annual deductible income are shown in Table 4.

Table 4: Results of annual deductible income of the valuated part of the model company XYZ in CZK

\begin{tabular}{|c|c|c|c|c|}
\hline Year & 2017 & 2018 & 2019 & $\begin{array}{c}\text { June } 30, \\
2020\end{array}$ \\
\hline Income & $4,600,600.40$ & $4,856,320.62$ & $4,862,449.22$ & $2,520,742.69$ \\
\hline Expenditure & $4,552,080.31$ & 4,874,389.98 & $4,633,439.81$ & $2,295,389.11$ \\
\hline Of which wages & $589,021.00$ & $771,695.00$ & $719,267.00$ & $378,020.00$ \\
\hline Profit & $48,520.09$ & $-18,069.36$ & $229,009.41$ & $225,353.58$ \\
\hline $\begin{array}{l}\text { Median gross } \\
\text { wage plus } \\
\text { compulsory } \\
\text { contributions } \\
\end{array}$ & $25,209.00$ & $28,518.00$ & $29,819.00$ & $30,840.00$ \\
\hline Annual salary & $302,508.00$ & $342,216.00$ & $357,828.00$ & $185,040.00$ \\
\hline \begin{tabular}{|ll}
$\begin{array}{l}\text { Share } \\
\text { cooperation }\end{array}$ & of \\
\end{tabular} & $10 \%$ & $10 \%$ & $10 \%$ & $10 \%$ \\
\hline \begin{tabular}{|ll} 
Salary & \\
depending on \\
the share of \\
cooperation
\end{tabular} & $30,250.80$ & $34,221.60$ & $35,782.80$ & $18,504.00$ \\
\hline Profit before tax & $18,269.29$ & $-52,290.96$ & $193,226.61$ & $206,849.58$ \\
\hline Tax $15 \%$ (FO) & $2,740.39$ & 0.00 & 28,983.99 & $31,027.44$ \\
\hline $\begin{array}{l}\text { Investment } \\
\text { intensity }\end{array}$ & $84,800.00$ & $84,800.00$ & $84,800.00$ & $84,800.00$ \\
\hline \begin{tabular}{|lr} 
Net deductible \\
annual income \\
\end{tabular} & $-69,271.10$ & $-137,090.96$ & $79,442.62$ & $91,022.14$ \\
\hline Weight & 1 & 2 & 3 & 4 \\
\hline
\end{tabular}

Source: Authors.

The permanently deductible net income has now been calculated according to formula 3 .

$$
T C V=\frac{\begin{array}{c}
1 *(-69,271.10 C Z K)+2 *(-137,090.96 C Z K)+ \\
3 * 79,422.62 C Z K+4 * 91,022.14 C Z K
\end{array}}{1+2+3+4} .
$$$$
T C V=62,305.20 C Z K \text {. }
$$

Permanently net deductible income was calculated at CZK 62,305.20 using formula 3.

In the next step, a discount rate was determined, which corresponds to the alternative cost of equity $\left(r_{e}\right)$ when using the earnings valuation method. First, the risk-free earnings $\left(r_{f}\right)$, which corresponds to the yield on a ten-year government bond, was obtained through the ARAD (CNB) time series database. At the valuation date, the value of the ten-year government bond yield was $0.86 \%$ (CNB, 2021). The values of the risk premium for business risk (rpod), risk premium for financial stability $\left(r_{\text {finstab }}\right)$ and risk premium for the size of the company $\left(r_{L A}\right)$ were obtained through the Ministry of Industry and Trade of the Czech Republic. Table 5 shows the values of the risk premium for business risk $\left(r_{p o d}\right)$, risk premium for financial stability 
$\left(r_{\text {finstab }}\right)$ and risk premium for the size of the company $\left(r_{L A}\right)$ for 2019.

Table 5: Values of risk premium for business risk $\left(r_{\text {pod }}\right)$, risk premium for financial stability $\left(r_{\text {finstab }}\right)$ and risk premium for company size $\left(r_{L A}\right)$ for 2019

\begin{tabular}{|l|l|}
\hline Risk premium for business risk $\left(r_{\text {pod }}\right)$ & $2.92 \%$ \\
\hline Risk surcharge for financial stability $\left(r_{\text {finstab }}\right)$ & $0.57 \%$ \\
\hline Risk premium for company size $\left(r_{L A}\right)$ & $1.69 \%$ \\
\hline
\end{tabular}

Source: MPO ČR, 2020.

The values of risk premiums for 2020 were not yet available at the date of valuation of the valuated part of the model company XYZ, and therefore the values of risk premiums from 2019 were used. At this point, the amount of alternative cost of equity was calculated according to formula 4 .

$$
\begin{gathered}
r_{e}=0.86 \%+2.92 \%+0.57 \%+1.69 \% . \\
r_{e}=6.04 \% .
\end{gathered}
$$

The calculated interest rate of alternative costs for equity for the valuation of the subject part of the model company XYZ using the income method was determined at $6.04 \%$.

It is now possible to calculate the value of the subject part of the model company XYZ using the earnings valuation method according to formula 5 .

$$
\begin{gathered}
H P=\frac{62,305.20 C Z K}{6.04 \%} . \\
H P=\mathbf{1}, \mathbf{0 3 1}, \mathbf{5 4 3} \mathrm{CZK} .
\end{gathered}
$$

The market value of the subject part of the model company XYZ was set at CZK 1,031,543 using the earnings valuation method. Then, the subject part of the model company XYZ was valuated using the asset valuation method. In the case of using the property valuation method, it was first necessary to determine the asset value of the identified operating and non-operating assets of the subject part of the model company XYZ. Table 6 shows the achieved results of total depreciation and residual prices of tangible fixed assets determined according to formulas 6 and 7. The passenger car (item ID 22) was not included in the calculation and is valuated in the next section.

\begin{tabular}{|c|c|c|c|c|}
\hline & C-D & & & \\
\hline 14 & $\begin{array}{l}\text { network } \\
\text { construction } \\
\text { technical } \\
\text { evaluation } \\
\end{array}$ & 6 years & $39,000.00$ & $91,000.00$ \\
\hline 15 & $\begin{array}{l}\text { Microwave contact } \\
\text { - C-D - technical } \\
\text { evaluation }\end{array}$ & 6 years & $27,138.00$ & $63,322.00$ \\
\hline 16 & Microwave contact & 5 years & $42,501.50$ & $127,504.50$ \\
\hline 17 & \begin{tabular}{|l} 
Microwave contact \\
2
\end{tabular} & 4 years & $35,914.00$ & $143,656.00$ \\
\hline 18 & $\begin{array}{l}\text { Microwave contact } \\
2\end{array}$ & 4 years & $16,740.40$ & $66,961.60$ \\
\hline 19 & $\begin{array}{l}\text { Microwave contact } \\
1\end{array}$ & 4 years & $18,600.80$ & $74,403.20$ \\
\hline 20 & \begin{tabular}{|l|} 
Microwave contact \\
3
\end{tabular} & 3 years & 8,999.25 & $50,995.75$ \\
\hline 21 & $\begin{array}{l}\text { Microwave contact } \\
4\end{array}$ & 3 years & $11,905.50$ & $67,464.50$ \\
\hline \multicolumn{4}{|c|}{ Total } & $1,207,936.17$ \\
\hline
\end{tabular}

Table 6: Total depreciation and residual value of tangible fixed assets in CZK

\begin{tabular}{|l|l|c|r|r|}
\hline ID & \multicolumn{1}{|c|}{ Name } & Asset age & $\begin{array}{c}\text { Total } \\
\text { depreciation }\end{array}$ & \multicolumn{1}{|c|}{$\begin{array}{c}\text { Residual } \\
\text { value }\end{array}$} \\
\hline 1 & $\begin{array}{l}\text { set of devices - } \\
\text { internet }\end{array}$ & 14 years & $67,154.35$ & $52,764.14$ \\
\hline 2 & $\begin{array}{l}\text { set of devices - } \\
\text { internet }\end{array}$ & 14 years & $64,634.35$ & $50,784.14$ \\
\hline 3 & Server & 14 years & $51,312.80$ & $40,317.20$ \\
\hline 4 & $\begin{array}{l}\text { set of devices - } \\
\text { internet }\end{array}$ & 13 years & $60,155.59$ & $55,528.24$ \\
\hline 5 & $\begin{array}{l}\text { set of devices - } \\
\text { internet }\end{array}$ & 13 years & $134,388.09$ & $72,362.82$ \\
\hline 6 & $\begin{array}{l}\text { Radio contact } \\
\text { ORCAVE }\end{array}$ & 12 years & $118,800.00$ & $79,200.00$ \\
\hline 7 & $\begin{array}{l}\text { radio contact - } \\
\text { antenna } \\
\text { parabola }\end{array}$ & 12 years & $56,220.00$ & $37,480.00$ \\
\hline 8 & $\begin{array}{l}\text { Microwave contact } \\
\text { A-B - No.1 }\end{array}$ & 10 years & $10,601.13$ & $10,601.13$ \\
\hline 9 & $\begin{array}{l}\text { Microwave contact } \\
\text { A-B - No.2 }\end{array}$ & 10 years & $10,601.13$ & $10,601.13$ \\
\hline 10 & $\begin{array}{l}\text { Microwave contact } \\
\text { A-B - No.3 }\end{array}$ & 10 years & $10,601.13$ & $10,601.13$ \\
\hline 11 & $\begin{array}{l}\text { Microwave contact } \\
\text { A-B - No.4 }\end{array}$ & 10 years & $10,601.13$ & $10,601.13$ \\
\hline 12 & $\begin{array}{l}\text { Invoice payment } \\
\text { No. 110100523 - } \\
\text { Server Dell }\end{array}$ & 9 years & $22,455.00$ & $27,445.00$ \\
\hline 13 & Microwave contact & 6 years & $27,575.40$ & $64,342.60$ \\
\hline
\end{tabular}

Source: Authors.

Tangible fixed assets are valuated using the asset valuation method in the amount of CZK 1,207,936.17.

The car (item ID 22) was valuated using the CebiaCat GT application. It was based on the type designation of the vehicle, the level of equipment, age and mileage at the date of the valuation. The car was valued at CZK 206,694 using the CebiaCat GT application. This amount therefore enters into the valuation of the subject part of the model company XYZ using the property valuation method.

Based on other provided accounting data of the subject part of the valuated model company XYZ, no current assets were identified and thus this part of the assets of the company XYZ does not enter into the valuation process using the property valuation method. Furthermore, financial assets in the total amount of CZK 199,183.10 were identified. These financial assets of the model company consisted of its receivables and cash in a bank account. Receivables from XYZ amounted to CZK 150,341 as of the valuation date and the current account balance was CZK $48,842.10$ as of the valuation date. The borrowed capital of XYZ was also determined in the form of outstanding liabilities in the total amount of CZK 467,468.45. These liabilities were deducted from the asset value of the valuated company XYZ. Table 7 shows the calculation of the value of the valuated company $X Y Z$ using the asset valuation

\begin{tabular}{|c|c|c|}
\hline & Entry & Value \\
\hline \multirow{2}{*}{ Fixed assets } & Passenger car & $206,694.00$ \\
\hline & Other fixed tangible assets & $1,207,936.17$ \\
\hline \multirow{2}{*}{$\begin{array}{l}\text { Financial } \\
\text { assets }\end{array}$} & Receivables & $150,341.00$ \\
\hline & Cash - Bank Account & $48,842.10$ \\
\hline $\begin{array}{l}\text { Borrowed } \\
\text { capital }\end{array}$ & Liabilities (-) & $-467,468.45$ \\
\hline \multicolumn{2}{|l|}{ Total } & $1,146,134.65$ \\
\hline
\end{tabular}
method.

Table 7: Valuation of XYZ using the asset valuation method in CZK

Source: Author.

The valuated subject of the model company XYZ was valued at CZK 1,146,134.65 using the assets valuation method.

\section{Discussion}

Different valuation methods can be used in different cases. Their choice always depends on the nature of the valuation's objective. For the valuation of companies that meet the condition of going concern, the earnings valuation method can be used and its use is logically justified. Asset valuation methods can be used to 
valuate companies that no longer meet the going concern condition. The property valuation method is thus more often used by companies that need to be valuated due to their liquidation, etc. In the model case of valuating a part of the company XYZ, both valuation methods were used, but each time with minor modifications of the input data. In the case of the earnings valuation method, tangible fixed assets were included in the valuation calculation in amounts determined on the basis of the investment intensity of individual items of tangible fixed assets. However, in the case of four items, their future renewal was not expected due to the nature of these assets, and thus these items did not enter the calculation of the valuation using the earnings method at all. In the case of using the asset valuation method, on the other hand, these four mentioned items of tangible fixed assets were included in the valuation, because at the valuation date these items were part of assets that the valuated part of the model company XYZ actually physically owned and used for its activities. This will be the case until the end of service life of these assets. The given difference in the results achieved by both used valuation methods of CZK $114,591.65$ could therefore be caused due to these stated and justified facts. It is also necessary to mention that in the case of valuation of the subject of valuation by the valuator, as an impartial independent rational person, the determined market value is always an estimate of the market price. However, the difference between this estimate and the final reality is minimized by the error-free use of all valuation methods utilized in a particular case. This difference can also be justified by the fact that the use of statistical methods also results in accuracy, which depends on the level of probability of achieving the calculated result. This is usually a 95\% level of probability, which corresponds to a difference of $+/-5 \%$ of the deviation of the established market price in the valuation and the final price.

The valuated part of the XYZ model company also does not have significant intangible assets related to the business (brand, etc.), nor does active marketing lead to the expansion of the customer base. If this were to happen, it would be able to collect higher profits only on the basis of the provision of internet connection and would not have to further invest in expanding the infrastructure of internet connection provision to gain new customers (access points).

\section{Conclusion}

The aim of the paper was to valuate a part of a company, which includes a set of all types of assets that the valuated part of the company uses for its activities. The valuation of this set was demonstrated on the example of the model company XYZ, which operates in the field of ICT. Specifically, it was a part of the company that provided internet connection services. Here, the specifics that are typical for this type of activity were identified and taken into account.

Subsequently, specific asset items of the valuated part of the model company XYZ were identified. The part of the model company XYZ was subsequently valuated using a selected earnings valuation method and subsequently also according to a selected asset valuation method.

The aim of the paper was thus met. Future research could focus on methods of identifying a set of operating and non-operating assets when valuating a portion of a company operating in other sectors.

\section{Literature:}

1. Abhayawansa, S., Aleksanyan, M., Bahtsevanoglou, J.: The use of intellectual capital information by sell-side analysts in company valuation. Accounting and Business Research. 2015, 45(3), 279-306 p. ISSN 0001-4788.

2. Audretsch, D. B., Link, A. N.: Valuing an entrepreneurial enterprise. Small Business Economics. 2012, 38(2), 139-145 p. ISSN 0921-898X.

3. Barba-Sanchez, V., Calderon-Milan, M., Atienza-Sahuquillo, C.: A Study of the Value of ICT in Improving Corporate Performance: A Corporate Competitiveness View.
Technological and Economic Development of Economy. 2018, 24(4), 1388-1407 p. ISSN 2029-4913.

4. Belvedere. V., Grano, A.: ICT-enabled time performance: an investigation of value creation mechanisms. Production Planning \& Control. 2017, 28(1), 75-88 p. ISSN 0953-7287.

5. Beran, V., Hromada, E.: Dynamic Simulations in Cost and Time Estimation of the Construction Process. Acta Polytechnica. 2008, 48(1), 30-35 p. ISSN 1210-2709.

6. Cassia, L., Vismara, S.: Valuation Accuracy and Infinity Horizon Forecast: Empirical Evidence from Europe. Journal of International Financial Management \& Accountuing. 2009, 20(2), 135-165 p. ISSN 0954-1314.

7. Ceská národní banka: Výnos desetiletých státních dluhopisů [Czech national bank: 10-year maturity Treasury bond yield] [online]. 2021. Available at: https://www.cnb.cz/cnb/stat.ARA DY_PKG.PARAMETRY_SESTAVY?p_strid=AEBA\&p_sestui $\mathrm{d}=375 \&$ \&_lang=CS (online: 18.2.2021)

8. Collewart, V., Manigart, S.: Valuation of Angel-Backed Companies: The Role of Investor Human Capital. Journal of Small Business Management. 2016, 54(1), 356-372 p. ISSN 0047-2778.

9. Fernández, P.: Most common errors in company valuation. Investment Management and Financial Innovations. 2005, 2(2), 128-141 p. ISSN 1810-4967.

10. Hidalgo, A., Herrera, R.: Innovation management and cocreation in KIBs: An approach to the ICT services sector. Technological Forecasting and Social Change. 2020, 161, Art. No. 120278. ISSN 0040-1625.

11. Informační systém o průměrném výdělku: Čtvrtletní výsledky - 1. čtvrtletí 2020: ČR celkem [Average earnings information system: Quarterly results - 1. Quarter 2020: CR total] [online]. v2020. Available at: https://www.ispv.cz/cz/Vysl edky-setreni/Archiv/2020.aspx (online: 18.2.2021)

12. Ionita, I., Stoica, M.: A New Approach Method of Company Valuation. Romanian Journal of Economic Forecasting. 2009, 10(1), 115-122 p. ISSN 1582-6163.

13. Jarmooka, Q., Fulford, R. G., Morris, R., Barratt-Pugh, L.: The mapping of information and communication technologies, and knowledge management processes, with company innovation. Journal of Knowledge Management. 2020, [Early Access]. ISSN 1367-3270.

14. Kim, D.: A 2020 perspective on "A dynamic model for the evolution of the next generation Internet - Implications for network policies": Towards a balanced perspective on the Internet's role in the $5 \mathrm{G}$ and Industry 4.0 era. Electronic Commerce Research and Applications. 2020, 41, Art. No. 100966. ISSN 1567-4223.

15. Kouki, A.: Accounting valuation models under international financial reporting standards: Evidence from some European listed companies. International Journal of Managerial and Financial Accounting. 2015, 7(1), 82-101 p. ISSN 1753-6715.

16. Langenstein, T., Uzik, M.: Specifics of Company Valuation of IT Companies. In: Gavurova, B., Soltes, M. (Eds.) Central European Conference in Finance and Economics (CEEF2015). Herlany, Slovakia, 2015, 347-356 p. ISBN 978-80-553-2467-8. 17. Lee, C. M., Chang, H.: A study on security strategy in ICT convergence environment. Journal of Supercomputing. 2014, 70(1), 211-223 p. ISSN 0920-8542.

18. Miciula, I., Kadlubek, M., Stepien, P.: Modern Methods of Business Valuation-Case Study and New Concepts. Sustainability. 2020, 12(7), Art. No. 2699. ISSN 2071-1050.

19. Mizik, N., Jacobson, R.: Valuing Branded Businesses. Journal of Marketing. 2009, 73(6), 137-153 p. ISSN 0022-2429. 20. Rowland, Z., Machová, V., Horák, J., Hejda, J.: Determining the Market Value of the Enterprise Using the Modified Method of Capitalized Net Incomes and Metfessel Allocation of Input Data. Ad Alta-Journal of Interdisciplinary Research. 2019, 9(2), 305-310 p. ISSN 1804-7890.

21. Sedláček, J.: Analysis of the Development of Intangible Assets in the Czech Enterprises and their Impact on Financial Position and Performance. Ekonomický Časopis. 2010, 58(4), 375-391 p. ISSN 0013-3035.

22. Stancu, I., Obrejabraşoveanu, L., Ciobanu, A., Stancu, A. T.: Are company valuation models the same? - A comparative analysis between the discounted cash flows (DCF), the adjusted net asset, value and price multiples, the market value added 
(MVA) and the residual income (RI) models. Economic Computation and Economic Cybernetics Studies and Research. 2017, 51(3), 5-20 p. ISSN 0424-267X.

23. Stehel, V., Hejda, J., Vochozka, M.: Use of Objectivized Value in Business Valuation. Ad Alta-Journal of Interdisciplinary Research. 2019b, 9(2), 333-338 p. ISSN 18047890.

24. Stehel, V., Rowland, Z., Mareček, J.: Valuation of Intangible Assets Deposit into Capital Company in Case of Specific Transaction. Ad Alta-Journal of Interdisciplinary Research. 2019a, 9(1), 287-291 p. ISSN 1804-7890.

25. Tuffnell, C., Král, P., Durana, P, Krulický, T.: Industry 4.0based manufacturing systems: Smart production, sustainable supply chain networks, and real-time process monitoring. Journal of Self-Governance and Management Economics. 2019, 7(2), 7-12 p. ISSN 2329-4175.

Primary Paper Section: A

Secondary Paper Section: AE, AH 